\title{
Grammar Errors in Acquiring Russian As a First and a Second Language
}

\section{Summary \\ Introduction}

It is intriguing how young children acquiring their native language can often master things that are beyond the power of people learning the very same language as adults.

Thus, for instance, it is usually quite difficult for learners of Russian as a second language to master the cases of nouns or aspects of the verb. Yet Russian babies acquire those categories with no special trouble. I select these categories, the noun cases and verbal aspects, as mastered by Russian babies and foreign speakers, for the purposes of this presentation. By analyzing the errors made by these groups of learners I intend to get to their cause and to see if the strategies of mastering Russian morphology are the same in acquiring Russian as the native language or as the second language.

Aim of the study - to compare grammar errors in the speech of children acquiring Russian as the first language and in the speech of Azerbaijani speakers acquiring Russian as the second language.

Materials and methods - the data I have collected consist of the samples from spontaneous speech or narratives from 10 Russian children aged 2 to 4 and two groups of Azerbaijani speakers, children aged 6 to 9 , and adults.

\section{Results and conclusions}

In language learning, should it be the first or the second language, mastering of the morphological categories requires linking the form and the content, the so-called form-functional mapping. A native speaking child finds the process easier due to a number of factors: (1) the language input is specific and aimed at the child's level of understanding; (2) the situations described by the statements are simple and observable; (3) as the language system is forming parallel to the cognitive one, knowledge of the world around goes hand in hand with mastering of the language units and categories, and the situation is ideal for establishing a strong tie between the form and the function.

Key words: first language acquisition, second language acquisition, errors, morphological categories.

\section{Introduction}

It is intriguing how young children learning their native language can often master things that are beyond the power of people learning the very same language as adults.

Thus, for instance, it is usually quite difficult for learners of Russian as the second language to master the case of nouns or the aspect of the verb. Yet Russian babies acquire those categories with no especial trouble. I select these categories, the noun case and the verbal aspect, as mastered by Russian babies and foreign speakers, for the purposes of this presentation. I intend, by analyzing the errors made by these groups of learners, to get to their cause and to see if the strategies of mastering Russian morphology are the same as in acquiring Russian as the native or as a second language.

\section{Aim of the study}

The aim of the study is to compare grammatical errors made by children learning Russian as the first language with those made by Azerbaijani speakers mastering Russian as the second language. 


\section{Materials and methods}

The data I have investigated consist of the samples of a spontaneous speech or narratives from 10 Russian children aged from 2 to 4 and two groups of Azerbaijani speakers, children aged 6 to 9 , and adults.

Do little children and foreign speakers learn a language in the same way or differently?

This has actually been debated for decades. One can find interesting data about how little children master language units and categories within their native language that pose serious difficulty for adults as second-language learners. One example of the above is the well-known situation concerning choosing the right article - the definite or the indefinite one - in learning English. We know that choosing the correct article is a fairly difficult task for anyone who is not a native speaker. At the same time Englishspeaking children make very few mistakes in the area. Thirty years ago Roger Brown noted that adult Japanese learning English as a second language do not seem able to learn how to use articles correctly, whereas a child learning English as the first language manages it just fine. Therefore Brown was inclined to see the learning process of the first language as a unique experience and thought that it might be different from the second language learning for adults (Brown 1973).

However, there is another, more widely held opinion stating that a second language is acquired in the same way as the first. One well-known researcher who holds to that is Barry Mac Laughlin. He has analyzed numerous papers written by his predecessors and concludes that "research in which adults acquiring a second language were compared to children acquiring the same language as a first language has shown that the adults pass through essentially the same developmental stages as children do in acquiring the target language" (McLaughlin 1984, 219).

Is this indeed so? We should remember that this conclusion was arrived at on the basis of languages without any morphological complexities, mostly English. There are reasons to believe that learning a language with a rich and complex morphological system (such as Russian) may result in a different picture.

Would, in particular, the morphological categories be mastered in a similar way in learning Russian as the first and as the second language? It is in this that the radical difference in languages should be especially obvious. "The differences in grammar categories are perhaps the most vivid and deep variations among natural languages" (Плунгян 2000, 109). One may therefore expect serious change in a person's linguistic consciousness in this particular area which would in some way manifest itself in the set up of one's mental lexicon, the way it is grammatically organized.

Therefore I have attempted to answer the question whether the morphological categories of the verbal aspect and the noun case are mastered similarly in learning a language as a first or a second language, analyzing errors in the speech made by Russian children aged 2 to 4 , as well as two groups of Azerbaijani speakers, children aged 6 to 9 , and adults.

I have chosen these two categories because they are the most difficult both for children and for foreign speakers. But I will attempt to illustrate that the difficulties for the two groups are not the same.

Taking a constructivist approach (D. Slobin, R. Berman, M. Tomasello) I hold that everyone constructs the grammar of the language she is learning in the mind (whether it is the first or the second language). In doing so we take the analysis of the received input done unconsciously as the basis, so that one goes through a series of ordered steps, moving from unconnected tiny facts to mastering the language as a system with all its grammatical categories.

I am comparing the first and the second language acquisition under natural circumstances without any formal teaching so that we have somewhat more equal conditions in which the individual is constructing the language system.

It is well known, that every category has the plane of content and the plane of expression, and is therefore bilateral in its essence. The plane of content consists, first and foremost, of semantics, and the plane of expression consists of grammatical markers: morphemes and their combinations that serve to express the content of the categories. Which is to say that mastering a morphological category means, accordingly, mastering the interrelation of the plane of content and the plane of expression. 
The category of aspect in Russian consists of two elements and it is based on the opposition of two grammatical forms: the perfect and the imperfect aspect, each uniting the form and the semantic function.

The main semantic difference between the perfect and the imperfect verbs is that the former describe an action as complete while the latter see it as incomplete. It is a perspective of the action that in Slavic languages is expressed through morphology. These two opposed meanings are realized in a number of semantic functions. The main function of the Perfect aspect is to describe a concrete "once over" fact limited by a boundary reached ( прочитал книгу [I have read the book] - Я читал книгу [I was reading, or I did read some of the book]). Verbs of the Imperfect aspect have two main functions - they denote an ongoing action (Посмотри: $\mathrm{OH}$ сидum u 4umaem [Look: he is sitting and reading]), or they denote a repeated action ( $\mathrm{OH}$ yumaem nо утрам [He usually reads in the morning]). Quite often the imperfect verbs are also used in the function of so-called generalized fact (Ты читал эту книгу? [Have you ever read this book?]), in this case the attention is on the result of the action, not on how it was going on.

Completeness and incompleteness is expressed by special markers used in forming aspect pairs. An aspect pair is two verbs denoting one and the same action, one as complete and indivisible, and another as incomplete. There are two ways of forming aspect pairs: the Perfect may be derived from the Imperfect by adding a prefix, or the Imperfect may be derived from the Perfect by adding suffixes to the base. A verb of Imperfect aspect may be formed by the suffixes $И B A, b I B A, A, B A$, added to the base of Perfect verbs. Derivation of the Imperfect verb from the Perfect looks as follows: Рассказать - рассказывать - to tell, narrate. Я рассказал об этом маме - Я ей всегда рассказывал [I told mother about it - I always told her things]; Разрушить - разрушать - to destroy - Время разрушило крепость. - Море медленно разрушало крепость (и наконец совсем разрушило). [Time has destroyed the stronghold] - [The sea was slowly destroying the stronghold (until it was quite destroyed)] or we can drop the prefix from a Perfect verb: nozacumb - zacumb: - to switch off, extinguish Погасumь cвеm? - Не надо гacumb. [Shall I switch off the light?] - [Do not switch off].

Sometimes a suppletive stem is used: положить - класть - to put down - Он положил книгу на место - Он всегда кладет книги на место [He has put the book back] - [He always puts a book back].

Thus, the morphological category of aspect shows a variety in both the plane of content (a set of semantic functions) and the plane of expression (a set of grammar markers).

The category of case consists of six elements and is based on the opposition of the Nominative, the Genitive, the Dative, the Accusative, the Instrumental, and the Prepositional case. Every case has a considerable number of semantic functions. Thus, for instance, the Instrumental case may denote an instrument of the action (nисать карандашом - to write with a pencil), an object of an emotional state (восхищаться сестрой - to admire the sister), and so on. The number of the semantic functions for every case is great enough, but with prepositions added it becomes quite overwhelming (говорить $C$ другом [to speak with a friend], спрятаться за забором [to hide behind the fence]), etc.

There are also many ways of marking the meanings of a case. In Russian the same case may be expressed not by one, but by all of the two flexions depending on the type of the declension which indirectly depends on the gender. Therefore in order to use the correct case form one has to know which of the three declension types the noun belongs to. Compare the same case in three nouns - nucamb ручкой, карандашом, тушью [to write with a pen, a pencil, ink].

The many existing functions and forms within Russian morphology make it extremely difficult to learn it correctly.

To master a morphological category means to know the potential semantic use (a set of semantic functions) that its every grammatical form has as well as the way each of its forms is built.

At the same time an obvious difference between the categories of the verbal aspect and of the noun case is that the members of the opposed aspect pair are different lexemes (an important point when trying to amass a mental lexicon), while the case forms are only a paradigm of forms of the same lexeme. This is why the two categories differ in their presence in the mental lexicon - the aspect of a verb is its constant characteristic in all instances of the use, and because of that it is mastered earlier in the ontogenesis than the case of nouns. To construct a case form one must know the noun paradigm that 
includes 12 forms ( 6 cases in the singular and the plural), and also to know which declension type the noun belongs to so that the correct affixation can be chosen.

The errors that are caused by insufficient knowledge of the semantic functions of the morphological categories, that is, choosing a morpheme that is inappropriate for the context, we may call Semantic errors. Errors in constructing a form we may call FORMAL errors.

Here are some examples of a child's speech that is under 1 year and 10 months old (Lisa). Verbs of the perfect aspect referring to a completed action in the past or future: Раздавила [crushed] (she has crushed a bug accidentally); Лизочка упала [little Lisa fell] (about herself); Уnaдy [I will fall] (about herself), Помоем [let us wash it] (suggests washing a teaspoon). Verbs of the imperfect aspect, denoting an action going on at the moment of speech: Лизочка коnaem [little Lisa is digging] (about herself), cnum [it sleeps] (of the dog), ползает [crawls] (about herself crawling on the floor). All the verbs are chosen correctly according to their semantic functions. The main semantic function of the verbs of both the perfect and imperfect aspect is mastered.

Now here are some errors made by foreign speakers: Тут он ВЫЛЕЗАЛ из стенки (instead оf ВЫЛЕЗ) [Then he WAS GETTING OUT of the wall (instead of GOT OUT)]; Можно мама к вам вечером ПРИХОДИТ? (instead of ПРИДЕТ) [Do you mind if mother KEEPS COMING to you in the evening?]; Я ей ДАВАЛА (instead of ДАЛА, ПОДАРИЛА) свою любИмую куклу [I WAS GIVING her my favourite doll, (she means gave as a present)]; Я СКАЗАЛА (instead of ГОВОРИЛА), а она писала [I SAID, and she was writing (instead of I WAS SPEAKING].

Trying to explain why children have no problem in the matter D. Slobin wrote the following words in the preface to his famous cross-linguistic series: "Notions of the verbal aspect are not only highly accessible to the child but they are so close to the meaning of the verb itself that children quickly learn to combine the meaning and the aspect of the verb in a single form learning separate forms for separate aspects easily" (Slobin 1986, 10). Slobin was entirely right about the linguistic reasons of the easy mastery - the closeness of the meaning of a verb and the meaning of its aspect. Every verb has its aspect fixed for it from the start, which determines its possible use for definite semantic functions. It is supported to a great extent by the characteristics of the input that is specific and intended for a small child. One might say that the aspect at once becomes a fact in the child's language consciousness (or even - of the subconsciousness).

Why then is the foreign speaker unable to select the appropriate morpheme? The main characteristic of every morphological category is that it always expresses a definite meaning within any sentence containing a verb (the meaning of the aspect is the action being complete or incomplete). But since in languages other than Slavic verbs do not automatically have an aspect, a foreign speaker sees the meaning of a verb separated from its aspect characteristics. So it happens that in a foreigner's mental lexicon any of the two elements of the aspect pair (usually related to the frequency on how often it is heard) becomes the term for the particular action, whether complete or incomplete, and will be used in every context.

Russian speaking children make most various types of errors in constructing the aspect pair: Разрушить - разрушивать (should be разрушать) - suffix ИВА used instead of $A$; Постелить постелять (should be стелить), the model for imperfectivation used instead of perfectivation (стелить-постелить); Заразить - разить (should ве заражать) - the model for perfectivation used instead of imperfectivation (заразить - заражать).

All these errors are examples of overgeneralization - an existing language rule is extended to cover a wider number of language units than it should.

So far I have not found any error of this kind among foreign speakers. Evidently this only supports what has been said earlier: since foreign speakers do not have the opposition of complete/incomplete action in their mind they do not feel the need for an aspect pair to exist - any of the verbs would serve to denote the action without distinguishing the specific aspect characteristics.

As to choosing the case, Russian speaking children have been observed to go through a short stage of the "frozen Nominative" which may take the place of other cases. This stage is not observed in all children, especially because it is so very short that may escape notice. By the age of two most children 
will have mastered the noun paradigm. Thus, Lisa E. began using cases in her speech over a period of 20 days when she was 1 year and 9 months old, and each case was used for several functions some of them only with fillers instead of the absent prepositions, and there was not a single instance of inappropriate use of a case form: Кого встречать будем? - Папу [Whom are we going to meet? - Papa.] (Accusative in the meaning of a direct object); Кому оставим? - Брату [Who shall we leave it to? - Brother.] (Dative in the meaning of the recipient); Чем буквы nuшуm? - КарандАшем - [What are letters written with? - A pencil.] - (Instrumental in the meaning of the instrument). Here we have an innovative form construction, the third syllable stressed, not the last one. This evidences that the child has been able to construct the form on her own since the noun paradigm has already been mastered.

I only have one error that could be classified as semantic - it is an instance of using the Accusative for a function it does not have, as related to the recipient, or rather, beneficiary: Почини Лизочку: [Fix Lisa, in the meaning of Fix this for Lisa].

Foreign speakers give us a very different picture. They have to construct sentences that include numerous components before they have mastered the cases with their semantic functions; therefore they use the strategy of simplification. Either they use the Nominative everywhere: Ябуду пятерка (should be пятерку) получать [I will get a five (top mark).] Nominative instead of Accusative; На бабушка надето (should be на бабушке) [Granny has put on] Nominative instead of Dative with preposition HA, or the Accusative takes the place of other oblique cases: Он волка сказал (should be волку) [He told the wolf] - Accusative instead of Dative; Я маму (should be маме) помогал [I was helping mother] - Accusative instead of Dative; Кто мне (should be на меня) смотрел? [Who was looking at me?] Dative instead of Accusative with preposition NA.

As to formal errors connected with constructing the case form (lexical form), they are frequent in the speech of Russian children and also occur in the speech of the second language learners. Here are some examples of formal errors children make: Есть ложком (should be ложкой) [To eat with a spoon] - Instrumental with the flexion of the second declension instead of the first; Под скатертей (should be скатертью) - [Under the table-cloth] - Instrumental with the flexion of the first declension instead of the third; Нет ни одного кусока (should be куска) [There is not a single piece] - the child is trying to keep the stem phonetically unified.

These kinds of mistakes occur also among foreign speakers but they are far less frequent.

This may be the evidence that in a child's mental lexicon words may be stored "dismantled", that is, there are not only lexemes but separate morphemes present, while the mental lexicon of a foreign speaker will probably contain the entire lexical form which are readily produced during speech production.

Here are several formal errors recorded from the speech attempts by foreign speakers. Most of them are efforts to keep the phonetic form of the base unchanged through various case forms: Они сидели у стОла (stress wrong) [They were sitting by the table]; Бандиты его нОжем (stress wrong) убили. [The bandits killed him with a knife]; сынОку (should be сынку) ничего не осталось [Nothing was left for the son] - the fugitive vowel was not omitted.

So far we have not recorded any errors with a mistaken choice of flexion among foreign speakers.

The errors that do occur and that are frequent enough are wrong constructions of the prepositionalcase forms, entirely impossible among young children. The preposition is usually chosen correctly but the case form itself is arbitrary: Скоро в школа (should be школу) [Time to go to school soon] - Nominative instead of Accusative; Волк гонялся за зайцам (should be за зайцами) - [A wolf was chasing hares] Dative instead of Instrumental; Они с медведей разговаривают - (should be с медведями) [They are talking to the bears] - Accusative or Genitive instead of Instrumental; На Север (should bе на Севере) они увидели медведя [In the North they saw a bear] - Accusative instead of Prepositional.

In this example there is probably no distinction made between the location and the direction which is unmarked in the foreign speaker's native language. Possibly this is an indirect influence of the first language like the examples without the aspect distinction.

How does our classification compare with the one used in the studies on the second language learning?

Literature related to the second language learning divides errors into two main groups: intralinguistic ones (developmental) and interlinguistic ones caused by the interference of another language. The 
intralinguistic ones are usually similar to the errors of children acquiring the same language as their native one. They are connected with the creative process of the language acquisition as such, be it the first language or the second, that is, they concern the fact that rules within a language are organized hierarchically and are mastered in a definite order (from general rules to the specific ones, and from those on to isolated forms). Also, these errors are practically independent of the differences with the foreign speaker's native language. They probably include those formal errors in cases that are connected with the tendency to keep the phonetic form of the stem unchanged. These errors are caused by the overgeneralization strategy.

Interlinguistic errors are considered to be caused by the interlinguistic interference, the pressure of the rules and models of the first language. However, most of the errors we recorded cannot be called interlinguistic unless we see interference as an unlimited sort of force. The majority of errors made by foreign speakers that we have recorded in the process of mastering the morphological categories of the verbal aspect and the case of nouns are caused by the very fact that the language system being acquired is secondary for the learner, and demands the expression of meanings that may not be present in their native language. As a result, the morphological category appears to be ignored which we can regard as a simplification strategy in a slightly wider sense that is usually accepted.

So why do small children whose native language is Russian manage the intricacies of Russian morphology better that foreign speakers?

Small children have an advantage because they construct short phrases reflecting their limited cognitive experience and sufficient for their communication needs. Language acquisition proceeds with the same speed as learning the relations of the surroundings, and cognitive and linguistic development march together in harmony.

An adult foreign speaker is sometimes left quite helpless when communication needs become much higher than the person's language ability. In such situations adults are forced to use the simplification strategy having to ignore that a particular morphological category exists in the target language - in our case the categories of verbal aspect or the case of nouns. This can be seen in the arbitrary choice of one grammatical form (for instance, one aspect without the regard to its semantic function), where the verb is chosen according to form that is better imprinted within the mental lexicon).

The reason the small children are so successful in mastering the plane of content of the category of the aspect seems to be that the first verbs that initially appear in the input, and then in the child's speech, are part of short and simple utterances describing easily observable situations with a clear division of continuing actions in the present that are not complete, and the completed actions in the past, with a result that can be seen as complete. The meaning of the completeness/incompleteness becomes seen as an integral characteristic of the verb and now belongs to it as a lexical unit within the forming mental lexicon. Since the child now has this orientation to the semantic function of aspect, it helps to choose correctly a verb that would express the continuity or repetition in an action.

Foreign speakers, on the other hand, quite often take one member of the aspect pair to describe the action irrespective of its complete/incomplete nature. Usually it is the verb that is better known as it has been experienced more frequently in the input.

\section{Conclusions}

In language acquisition, should it be the first or the second language, mastering of the morphological categories requires connection between the form and the content or the so-called form-functional mapping. A native speaking child finds the process made easier by a number of factors:

- The language input is specific and aimed at the child's level of understanding since adults being with a child choose as a rule the prototypic means for expressing prototypic functions, limiting initially the rich variation of the language forms and functions which could make learning difficult.

- The situations described by the statements are simple and observable.

- A certain monotony in the child's communication intentions needs to be expressed in speech. 
- The fact that the language system is being formed parallel to the cognitive one (knowledge about the world around goes hand in hand with mastering language units and categories) is ideal for setting up a strong tie between the form and the function, making the language elements more solid. For a second language learner the situation may, in this sense, be more complicated.

- The input received is varied and multi-faceted not specifically targeted at a foreign speaker.

- Communication goes on at a much more complex level, and there is infinitely more information expressed and received.

- A conflict is possible between the language skills one already has and those being acquired since through having to express morphological meanings one has to focus attention on such facets that may not initially have been the part of the intended communication, like completeness and incompleteness of an action.

What first and second language learners have in common when mastering Russian morphology is the construction of the morphological system, passing from rote-knowledge step, through several intermediate stages, to rule-knowledge step (the terms from (Berman 2004)). The difference is in the volume of the language units used in forming utterances (in the first language acquisition morphemes are more active than word-forms), and in semantic specialization.

\section{References}

1. Berman, R. (2004). Between emergence and mastery. The long development route of language acquisition. Language development across Childhood and Adolscience, p. 14.

2. Slobin, D. (1986). Introducton: Why Study Acquisition Crossinguistically? In: Jill G. de Villiers, Peter A. de Villiers. The Acquisition of English Hillsdale (p. 10). New Jersey, London: Erlbaum.

3. Brown, R. (1973). Development of the first language in the human species. American Psychologist. 1973/28/97, p. 106.

4. Barry, McLaughlin (1984). Second Language Acquisition in Childhood. Preschool Children. Vol. 1, p. 219.

5. Плунгян, В. А. (2000). Общая морфология. Введение в проблематику [General Morphology. Introduction in a Problematics]. Москва: Эдиториал URSS, c. 109 (in Russian).

\section{Prof. Dr. philol. Stella N. Ceytlin}

Herzen State Pedagogical University of Russia

Address: Moskovskiy prospect 80, St. Petersburg, 191186, Russia

Address: Moika Emb, 48, 191186, St. Petersburg, Russia

Phone: 00-7-812-2526653

E-mail: stl2006@list.ru 